\title{
Experimental Organism Ductal Cell Adenoma
}

National Cancer Institute

\section{Source}

National Cancer Institute. Experimental Organism Ductal Cell Adenoma. NCI Thesaurus.

Code C156610.

An experimental org anism adenoma that arises from a ductal structure. 